\title{
Recurrent Neural Network With Gate Recurrent Unit For Stock Price Prediction
}

Recurrent Neural Network Dengan Gate Recurrent Unit Untuk Prediksi Harga Saham

\section{Afif Ilham Caniago' ${ }^{1}$, Wilis Kaswidjanti², Juwairiah $^{3}$}

\author{
1, 2, 3 Informatika, Universitas Pembangunan Nasional Veteran Yogyakarta, Indonesia \\ 19afifilhamcaniago@gmail.com, ${ }^{2}$ wilis.kas@gmail.com, ${ }^{3}$ juwairiah@upnyk.ac.id \\ *corresponding author
}

\section{Informasi Artikel}

Received: August 2021

Revised: September 2021

Accepted: September 2021

Published: October 2021

\begin{abstract}
Stock price prediction is a solution to reduce the risk of loss from investing in stocks go public. Although stock prices can be analyzed by stock experts, this analysis is analytical bias. Recurrent Neural Network (RNN) is a machine learning algorithm that can predict a time series data, non-linear data and non-stationary. However, RNNs have a vanishing gradient problem when dealing with long memory dependencies. The Gate Recurrent Unit (GRU) has the ability to handle long memory dependency data. In this study, researchers will evaluate the parameters of the $R N N-G R U$ architecture that affect predictions with MAE, RMSE, DA, and MAPE as benchmarks. The architectural parameters tested are the number of units/neurons, hidden layers (Shallow and Stacked) and input data (Chartist and TA). The best number of units/neurons is not the same in all predicted cases. The best architecture of RNN-GRU is Stacked. The best input data is TA. Stock price predictions with RNN-GRU have different performance depending on how far the model predicts and the company's liquidity. The error value in this study (MAE, RMSE, MAPE) constantly increases as the label range increases. In this study, there are six data on stock prices with different companies. Liquid companies have a lower error value than non-liquid companies.
\end{abstract}


Keywords: stock exchange; RNN ; GRU; Shallow, Stacked, Tecnical analysis, Chartist

Kata kunci: Saham; RNN; GRU; Shallow; Stacked; Tecnical analysis, Chartist

\begin{abstract}
Abstrak
Prediksi harga saham merupakan solusi untuk mengurangi resiko kerugian dari investasi pada saham yang go public. Walaupun harga saham dapat dianalisis oleh para pakar saham, namun analisis ini bersifat bias analisis. Recurrent Neural Network (RNN) merupakan algoritma pembelajaran mesin yang dapat melakukan prediksi terhadap data saham yang bersifat time series, data non linear dan non stationary. Namun RNN mempunyai masalah vanishing gradient ketika berhadapan dengan data yang bersifat long memory dependency. Gate Recurrent Unit (GRU) mempunyai kemampuan dalam menangani data yang bersifat long memory depedency. Pada penelitian ini peneliti akan melakukan evaluasi pada parameterparameter arsitektur RNN-GRU yang mempengaruhi prediksi dengan tolak ukur MAE,RMSE,DA, dan MAPE. Parameter arsitektur yang diuji adalah jumlah unit/neuron, hidden layer(Shallow dan Stacked) dan data input (Chartist dan TA). Jumlah unit terbaik tidak sama pada semua kasus prediksi. Arsitektur terbaik RNN-GRU adalah Stacked. Data input terbaik adalah TA. Prediksi harga saham dengan RNN-GRU memiliki performa yang berbeda beda tergantung berapa jauh model memprediksi dan liquiditas perusahaan. Nilai error pada penelitian ini (MAE, RMSE, MAPE) secara konstan naik seiring dengan bertambahnya rentang label. Pada penelitian ini terdapat enam data harga saham dengan perusahaan berbeda. Perusahaan liquid memiliki nilai error yang lebih rendah daripada perusahaan non liquid.
\end{abstract}

\section{Pendahuluan}

Saham merupakan surat berharga yang memberikan peluang keuntungan yang tinggi namun juga berpotensi risiko tinggi. Dengan fluktuasi harga saham yang tinggi, saham juga dapat membuat investor mengalami kerugian besar dalam waktu singkat [20]. Fluktuasi ini terjadi karena faktor-faktor ekonomi yang terjadi secara tiba-tiba dan susah diprediksi. Untuk itu investor membutuhkan sistem prediksi yang dapat membantu dalam mengambil keputusan investasi pembelian saham.

Data pada pergerakan harga saham memiliki tiga isu yaitu bersifat nonlinear, nonstationary, dan memiliki long memory dependency [4]. Pergerakan harga saham dipengaruhi berbagai hal namun faktor ekonomi, performa perusahaan dan psikologi pasar adalah faktor yang sangat berpengaruh. Hal ini membuat pergerakan saham bersifat nonlinear dan nonstationary [4]. Secara statistik para pakar saham menggunakan analisis teknikal dalam memprediksi harga saham. Namun teknik ini bersifat subjektif dan bias analisis karena analisis pakar satu dengan 
yang lainnya dapat berbeda tergantung dari pengalaman dan pemilihan Tecnical Indicator yang digunakan [4].

Data pergerakan harga saham merupakan data time series Sehingga membuat adanya keterikatan pengaruh data masa lampau secara beruntun. Pendekatan komputasional telah banyak dilakukan dalam memprediksi pergerakan harga saham. [14] membandingkan metode Autoregressive Integrated Moving Average (ARIMA), Artificial Neural Network (ANN) dan hybrid ANN-ARIMA dengan dua dataset berbeda yaitu ASPI dan SL20 dengan hasil pada dataset ASPI adalah MAE ARIMA sebesar 62,7512 ,MAE ANN sebesar 36,9834, MAE ANN-ARIMA sebesar 21,2208 dan dataset SL20 adalah MAE ARIMA sebesar 28,8660 ,MAE ANN sebesar 19,8767, MAE ANN-ARIMA sebesar 14,1000. Rata-rata performa akurasi yang menggunakan metode T-test adalah ANN (75,74\%) lebih baik ketimbang SVM $(71,52 \%)$ [9]. ANN merupakan metode yang sering dipakai ketika menghadapi data yang bersifat nonlinear dan nonstationary. [13] mengatakan ANN dapat digunakan untuk memprediksi data time series yang tidak beraturan (non linear). ANN dapat memprediksi data yang mempunyai dimensi data yang tinggi dan dapat mempelajari fluktuasi dari data yang nonlinear dan nonstationary [6].

Salah satu model dari ANN yang cukup populer dalam prediksi dan klasifikasi data time series adalah Recurrent Neural Networks (RNN). RNN cocok dipakai pada dataset yang bersifat time series karena model ini memiliki kemampuan dalam mempelajari data sequence di mana output jaringan bergantung pada jumlah yang berubah ubah dari input sebelumnya. RNN dapat menjadi model yang berguna untuk membuat prediksi deret waktu yang tidak beraturan, terutama dalam membuat prediksi multi-step [7]. Namun RNN memiliki kelemahan dalam menghadapi prediksi dengan frame waktu yang cukup panjang yang mana permasalahan ini lebih dikenal dengan long memory dependency. Karena RNN akan mengalami permasalahan yang dinamakan Vanishing Gradient dan Gradient Exploding apabila RNN menangani masalah prediksi dengan panjang range waktu yang panjang [19]. Gated Recurrent Unit (GRU) datang sebagai pengembangan lebih lanjut dari unit RNN konvensional yang memiliki kemampuan dalam menangani kasus prediksi dan klasifikasi tanpa adanya permasalahan Vanishing Gradient dan Gradient Exploding [19]. GRU merupakan unit RNN yang merupakan sebuah model machine learning merupakan pengembangan dari unit Long Short Term Memory (LSTM). GRU merupakan penyederhanaan dari LSTM yang berupa pengurangan gate dan parameter untuk mempercepat waktu pelatihan dan mempermudah implementasi [1].

Dari permasalahan tersebut maka dapat dirancang sebuah model machine learning dengan menggunakan metode Recurrent Neural Networks dengan unit Gated Recurrent Unit (RNNGRU) dengan melakukan evaluasi terhadap beberapa parameter baik dari sisi data maupun dari sisi model dengan harapan model GRU dapat melakukan prediksi terhadap pergerakan harga saham dengan error yang rendah.

\section{Metode}

Pada penelitian ini terdapat empat tahapan utama yaitu pengumpulan data, Pra processing data, Pengujian Arsitektur, dan pengujian regulasi dropout. Ilustrasi dari metode penelitian ini terdapat pada Gambar 1. Berikut adalah tahapan dari penelitian ini. 


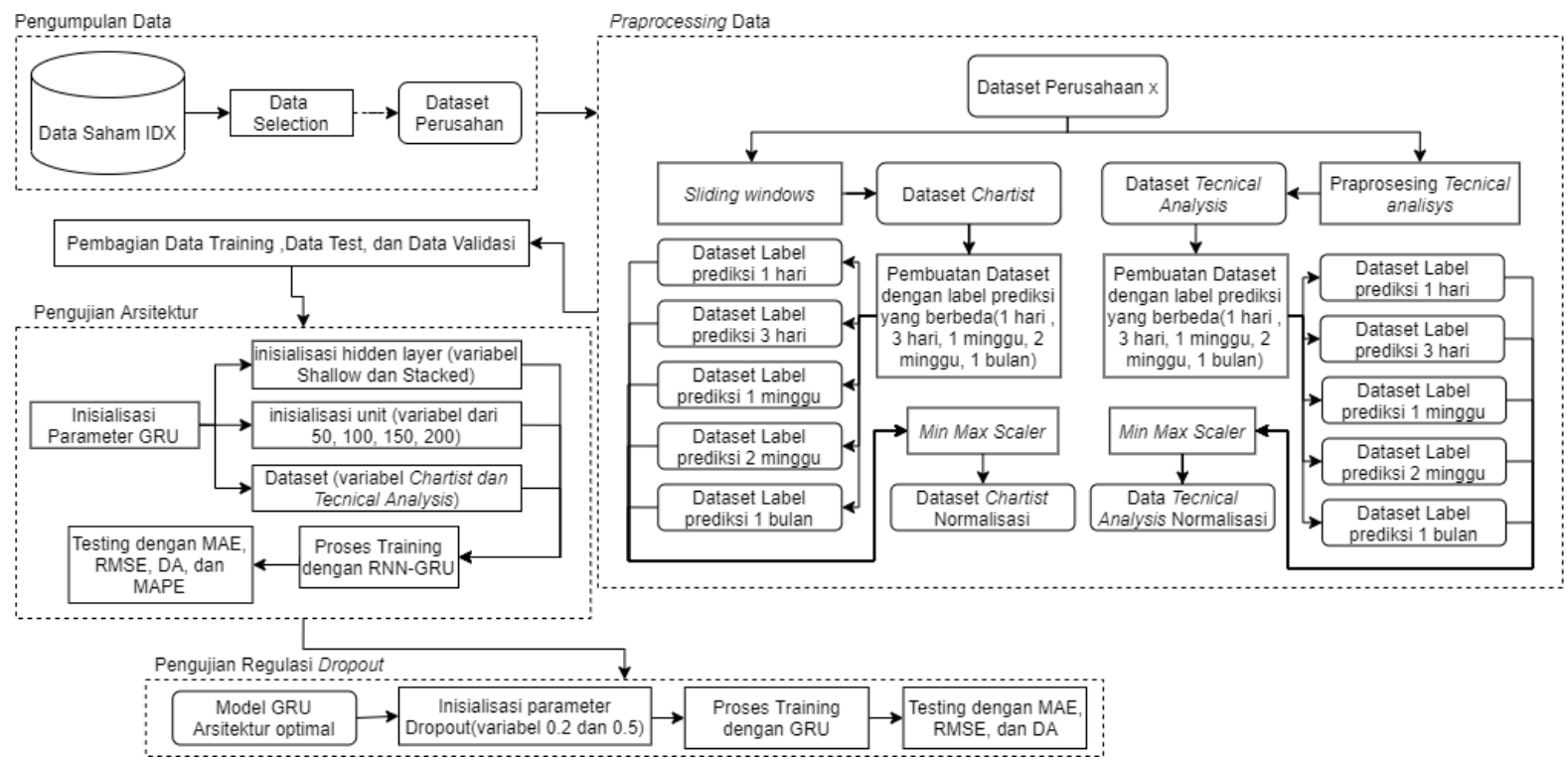

Gambar 1. Metodologi Penelitian

\subsection{Pengumpulan Data}

Data yang dipakai pada penelitian ini didapatkan dari website Stock Exchange Indonesia (IDX) (https://www.idx.co.id/data-pasar/ringkasan-perdagangan/ringkasan-saham/). Data yang diambil merupakan data dengan rentang dari tahun 2015 sampai tahun 2019. Data yang diambil berupa data harga saham harian. Fitur yang diperlukan pada penelitian ini adalah harga pembuka (open), harga tertinggi (high), harga terendah (low), harga penutupan (close), dan Volume yang disingkat OHLCV.

Tabel 1. Daftar Dataset yang digunakan

\begin{tabular}{lll}
\hline Sektor & Saham & Quote \\
\hline \multirow{2}{*}{ Mining } & PT. Adaro Energy Tbk & ADRO \\
\cline { 2 - 3 } & PT. Vale Indonesia Tbk & INCO \\
\hline \multirow{2}{*}{ Miscellenous } & PT. Astra International Tbk & ASII \\
\cline { 2 - 3 } & PT. Indomobil Sukses Internasional Tbk & IMAS \\
\hline \multirow{2}{*}{ Infrastructure } & PT.Telekomunikasi Indonesia (Persero) Tbk & TLKM \\
\cline { 2 - 3 } & PT. Garuda Indonesia (Persero) Tbk & GIAA \\
\hline
\end{tabular}

Dataset yang dipakai dipilih berdasarkan dua jenis saham berdasarkan tingkat liquiditas yang berbeda yaitu tinggi dan rendah. Dataset yang dipakai dipilih berdasarkan dua jenis saham berdasarkan tingkat liquiditas yang berbeda yaitu tinggi dan rendah. Liquiditas adalah kemampuan suatu perusahaan dalam melunasi hutang atau bisa diartikan kualitas kinerja suatu perusahaan. Dataset berasal dari tiga sektor yang berbeda yang terdaftar pada Jakarta Stock Industrial Classification (JASICA). Tabel 1 adalah daftar perusahaan yang akan diujikan dengan higlight biru adalah saham dengan Liquid dan yang tidak di-highlight adalah saham Non-Liquid.

\subsection{Data Preprocessing}

Ada dua bentuk dataset yang akan diujikan pada penelitian ini yaitu data dengan bentuk Tecnical Analysis (TA) dan Chartist. Dataset TA akan menggunakan 10 Tecnikal Indicator 
(TI). Indikator teknis (Tecnikal Indicator) berguna dalam memprediksi kecenderungan arah pergerakan saham. Data input TA juga diterapkan pada penelitian [9] dan [4]. Tecnikal Indicator ini merupakan nilai-nilai yang dipakai oleh para broker saham ketika melakukan analisis saham. Terdapat 10 Tecnikal Indicator yang akan digunakan seperti yang tertampil di Tabel 2 yang merujuk pada penelitian [9]. Pada Tabel 2 terdapat parameter validasi yang harus ditetapkan untuk menghitung nilai Tecnikal Indicator yang akan digunakan. Dasar pemilihan nilai parameter pada TA dirujuk dari penelitian [4]. Chartist adalah metode proses analisis saham yang hanya melihat dari fitur dasar yaitu harga pembuka (opening), harga terendah (low), harga tertinggi (high) dan harga penutupan (close) (OHLC) [4]. Chartist merupakan data mentah pergerakan harga saham.

Tabel 2. Parameter Tecnical Analysis

\begin{tabular}{lll}
\hline No & Tecnical Analysis & Validasi \\
\hline 1 & Simple 10-day Moving Average $($ SMA10) & Time period $=10$ \\
\hline 2 & Weighted 10-day Moving Average $($ WMA10) & Time period $=10$ \\
\hline 3 & Momentum $(\mathrm{M})$ & Time period $=10$ \\
\hline 4 & Stochastic K\% (K\%) & K period $=5$ \\
\hline 5 & Stochastic D\% (D\%) & D period $=3$ \\
\hline 6 & Relative Strength Index $(\mathrm{RSI})$ & Time Period $=14$ \\
\hline 7 & Moving Average Convergence Divergence $(\mathrm{MACD})$ & Fast period $=12$ \\
& & Slow Period $=26$ \\
\hline 8 & Larry William's R\% (R\%) & Time Period $=14$ \\
\hline 9 & Accumulation / Distribution Oscillator $(\mathrm{A} / \mathrm{D})$ & Time Period $=10$ \\
\hline 10 & Commodity Channel Index $(\mathrm{CCI})$ & Time Period $=14$ \\
\hline
\end{tabular}

Dalam tahapan ini kegiatan yang dilakukan adalah menganalisis kebutuhan untuk membuat sistem informasi manajemen notulensi. Yang pertama adalah proses analisis dengan dasar hasil wawancara yang sudah dilakukan dengan bagian monitoring dan evaluasi (monev) $\mathrm{CV}$. Sinergi Telematika Yogyakarta.

Praprocessing data pada setiap bentuk dataset (TA atau Chartist) akan dilakukan dengan 3 tahapan yang sama yaitu pembentukan dataset, pelabelan dan min max scaler. Pembentukan dataset pada dataset TA dan chartist berbeda. Dataset TA akan didapatkan dengan mengubah data OHLCV menjadi Tecnikal Indicator melalui rumus yang tertera diaatas. Dataset TA akan diimplementasikan menggunakan library python ta-lib (https://github.com/mrjbq7/ta-lib). Dataset Chartist akan menerapkan proses sliding window yaitu proses agar dataset mentah harga saham memiliki suatu time step tertentu. Ilustrasi data yang di terapkan sliding window terdapat pada Gambar 2.

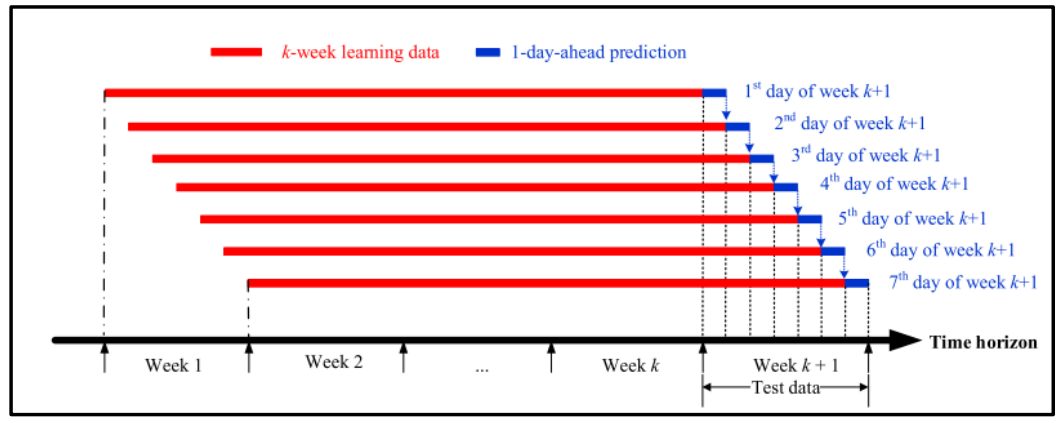

Gambar 2. Ilustrasi Sliding Window 
Pada penelitian ini terdapat lima label berbeda yang akan diuji satu persatu. Lima label tersebut adalah time period atau rentang jauh prediksi yaitu 1 hari, 3 hari, 1 minggu, 2 minggu, dan 1 bulan. Apabila dataset dilabeli 1 minggu maka nilai aktual pada suatu dataset adalah 1 minggu kedepan dari satu set data. setelah diberi label kemudian data akan dinormalisasi dengan min max scaler agar setiap fitur tidak terlalu sensitif terhadap satu fitur tertentu.

\subsection{Proses Partisi Data}

Proses sebelum melakukan proses uji arsitektur RNN-GRU yaitu pembagian dataset. Dataset akan dibagi kedalam tiga bagian yaitu training, validation, dan testing. Panduan baku dalam menentukan jumlah partisi data ini belum mempunyai aturan baku. Menurut [10] partisi yang paling sering dipakai adalah $70 \%$ data training dan $30 \%$ data testing. Pada penelitian ini akan menggunakan $70 \%$ data training, $10 \%$ data validasi, dan $20 \%$ data testing. Data training merupakan data yang akan dilatih didalam jaringan. Data validation adalah data uji dalam training, data ini akan dilatih ketika data training sudah dilatih terlebih dahulu. Data testing adalah data yang digunakan untuk menguji model. Berikut rumus min max scaler:

$x_{\text {scaled }}=\frac{x-\min (x)}{\max (x)-\min (x)}$

Keterangan: $x=$ data

\subsection{Gated Recurrent Unit (GRU)}

Gated Recurrent Unit (GRU) adalah model RNN yang telah dikembangkan dalam mengatasi masalah long memory dependency ketika menghadapi data dengan frame waktu yang panjang karena RNN akan mengalami Vanishing Gradient ketika melakukan BTT [21]. Pada Gambar 3 terlihat bagaimana implementasi GRU pada RNN. GRU merupakan pengembangan dari metode Long Short Term Memory (LSTM). Kelebihan dari GRU adalah bobot dan parameter yang di latih lebih sedikit dari LSTM sehingga kecepatan pelatihan model lebih cepat dari pada LSTM dan implementasi GRU yang lebih sederhana dari LSTM [17]. Bobot latih dan parameter GRU lebih sedikit daripada LSTM karena Gate GRU lebih sedikit daripada LSTM. LSTM memiliki tiga gerbang yaitu forget gate(f_t), input gate $\left(i \_t\right)$, dan output gate(O_t). GRU menggabungkan gerbang forget dan input menjadi update gate $(\mathrm{z})$. Gerbang kedua dari GRU adalah reset gate (r). Apabila ouput yang dihasilkan LSTM ada dua nilai yaitu hidden state dan cell state maka Output dari GRU hanya satu yaitu hidden state [2]. Ilustrasi gerbang GRU terdapat pada Gambar 2. Berikut persamaan pada gerbang-gerbang GRU:

$$
\begin{aligned}
& z_{t}=\sigma\left(W_{z} x_{t}+U_{z} h_{t-1}+b_{z}\right) \\
& r_{t}=\sigma\left(W_{r} x_{t}+U_{r} h_{t-1}+b_{r}\right) \\
& \tilde{h}_{t}=\tanh \left(W_{h} x_{t}+U_{h}\left(r_{t} \odot h_{t-1}\right)+b_{h}\right) \\
& h_{t}=\left(1-z_{t}\right) \odot h_{t-1}+z_{t} \odot \tilde{h}_{t}
\end{aligned}
$$

Keterangan :

$z_{t} \quad=$ update gate

$r_{t} \quad=$ reset gate

$\tilde{h}_{t} \quad=$ candidates value

$h_{t} \quad=$ output atau hidden state

$h_{t-1}=$ output dari state
$W_{z}=$ bobot update yang terkoneksi dengan input

$W_{r}=$ bobot reset yang terkoneksi dengan input

$W_{h}=$ bobot candidates yang terkoneksi dengan input

$U_{z}=$ bobot update yang terkoneksi dengan output 


$\begin{array}{llrl} & \text { Sebelumnya } & & \text { sebelumnya } \\ \sigma & =\text { sigmoid } & U_{r} & =\text { bobot } \text { reset yang terkoneksi dengan output } \\ \tanh = & \text { fungsi aktivasi tanh } & \text { sebelumnya } \\ x_{t}=\text { input } & U_{h}= & \text { bobot } \text { candidates yang terkoneksi dengan } \\ h_{t-1}=\text { output sebelumnya } & & \text { output } \text { sebelumnya } \\ b_{z}=\text { bias } \text { update } & b_{r}=\text { bias } \text { reset } \\ & & b_{h}=\text { bias } \text { candidates }\end{array}$

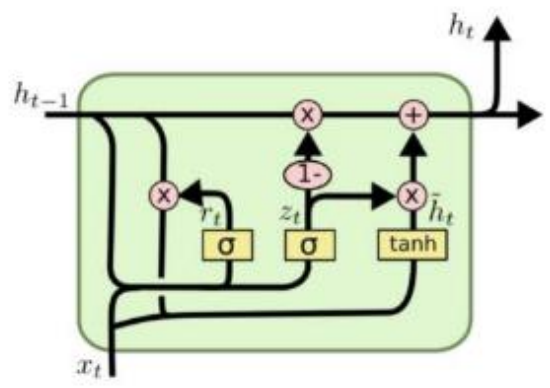

Gambar 2. Arsitektur Modul GRU

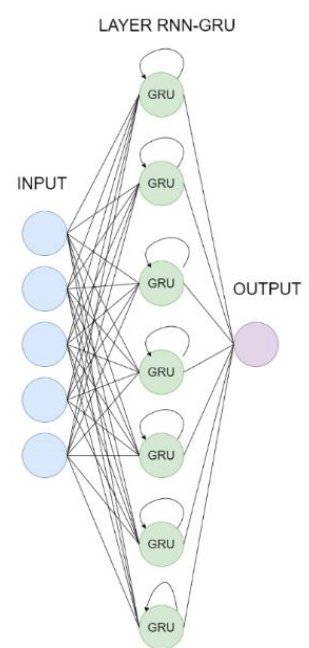

Gambar 3. Arsitektur RNN-GRU

\subsection{Pengujian Arsitektur}

Pengujian arsitektur mempunyai tujuan untuk menemukan arsitektur atau hyperparamaeter terbaik yang dapat memprediksi harga saham dengan tepat. Pengujian arsitektur menggunakan tiga parameter yaitu banyaknya unit GRU di hidden layers (50, 100, 150, dan 200), Hidden layer (Shallow dan Stacked) dan Data Input (Chartist dan TA). Shallow adalah arsitektur RNN-GRU satu layer. Stacked adalah arsitektur RNN-GRU lebih dari satu layer dengan arah time step yang sama dengan layer sebelumnya. Pada penelitian ini arsitektur stacked mempunyai 2 layer. Sebelum membandingkan tiga hyperparameter (banyak Unit, Hidden Layer, dan Data input) tersebut, jaringan ANN mempunyai parameter lainnya yang harus diinisialisasi terlebih dahulu diantaranya seperti pada Tabel 3. Tolak ukur kemampuan model akan diukur dengan empat nilai yaitu Mean Absolute Error (MAE), Root Mean Squared Error 
(RMSE), Directional Accuracy (DA), dan Mean Absolute Percetage Error (MAPE). Pengujian dilakukan dengan tahapan inisialisasi hyperparameter tetap seperti Tabel 3, kemudian hyperparameter yang diujikan akan dinisiasi, lalu dilakukan proses training. Training akan dilakukan dengan kombinasi hyperparameter yang diujikan. Setiap kombinasi hyperparameter akan diujikan dengan lima label yang berbeda dan unit GRU yang berbeda. Perbandingan pada penelitian akan dibagi lima bagian sesuai dengan jumlah label sehingga label yang berbeda tidak dapat dibandingkan. Setelah melakukan training, data testing dan hasil prediksi harus melewati proses Denormaslisasi. Denormalisasi adalah proses mengembalikan nilai-nilai yang sudah di praprocessing kembali menjadi nilai-nilai sebelum di praprocessing. Pada penelitian ini praprocessing yang merubah nilai dataset adalah Min Max Scaler. Proses Denormaslisasi untuk praprocessing Min Max Scaler adalah membalik rumus Min Max Scaler.

Tabel 3. Parameter RNN-GRU tetap

\begin{tabular}{lll}
\hline No & Parameter & Validasi \\
\hline 1 & Unit layer output & 1 \\
\hline 2 & Fungsi aktivasi output & Sigmoid \\
\hline 3 & Epoch & 300 \\
\hline 4 & Optimasi gradient descent & ADAM \\
\hline 5 & Batch & 252 \\
\hline 6 & Loss function & MAE \\
\hline
\end{tabular}

\subsection{Pengujian Dropout}

Dropout merupakan regulasi untuk menghindari overfitting. Metode ini diimplementasikan dengan menambahkan layer diantara 2 hidden layer yang mana layer ini akan mematikan neuronnya agar jaringan tersebut terputus. Layer Dropout berada diantara Hidden layer. Berapa banyak neuron yang mati akan ditentukan dengan parameter yang diberikan. Parameter yang akan diujikan adalah $(0,2)$ dan $(0,5)$. Untuk penentuan parameter dropout belum ada ketentuan khusus sampai sekarang. Pengujian Dropout hanya akan menguji model terbaik dari setiap pengujian arsitektur. Dropout akan diujikan pada model dengan unit terbaik pada setiap model dengan arsitektur hidden layer dan data input yang berbeda.

\section{Hasil dan Pembahasan}

Hasil pada penelitian ini akan dijabar secara terpisah sesuai label dan penerapan regulasi dropout akan dijelaskan secara terpisah. Pengujian model RNN-GRU telah dilakukan dengan jumlah unit $(50,100,150,200)$ pada setiap model dengan kombinasi arsitektur hidden layer dan data input yang berbeda. Nilai MAE terbaik akan menjadi tolak ukur utama dalam memilih model dengan jumlah unit terbaik. Setelah diuji, model dengan jumlah unit terbaik akan dipilih dan dibandingkan dengan model lainnya pada perusahaan yang sama untuk diukur Arsitektur hidden layer dan data input apa yang terbaik. Pada perbandingan perusahaan, nilai MAPE yang dibandingkan adalah nilai MAPE terendah pada hasil perbandingan arsitektur hidden layer dan data input.

\subsection{Label 1 Hari}

Tabel 4 adalah daftar model dengan nilai pengujian (MAE, RMSE, DA, MAPE) terbaik pada jumlah unit di setiap perusahaan, arsitektur, dan data input dengan label 1 hari. 
Tabel 4. Nilai metode pengujian jumlah unit GRU terbaik

\begin{tabular}{|c|c|c|c|c|c|c|}
\hline Perusahaan & Arsitektur & $\begin{array}{l}\text { Input } \\
\text { Data }\end{array}$ & MAE & RMSE & DA & MAPE \\
\hline \multirow{4}{*}{$\begin{array}{l}\text { PT. } \\
\text { Energy } \\
\text { (ADRO) }\end{array}$} & \multirow[t]{2}{*}{ Shallow } & Chartist & 31,27234043 & 42,3238276 & 52,99145299 & 2,36199423 \\
\hline & & TA & 42,14529915 & 47,04108043 & 92,70386266 & 3,326586746 \\
\hline & \multirow[t]{2}{*}{ Staked } & Chartist & 29,26382979 & 39,45193682 & 51,28205128 & 2,222242485 \\
\hline & & TA & 11,04700855 & 14,84406123 & 93,13304721 & 0,836404594 \\
\hline \multirow{4}{*}{$\begin{array}{l}\text { PT. } \\
\text { Indonesia } \\
\text { (INCO) }\end{array}$} & \multirow[t]{2}{*}{ Shallow } & Chartist & 79,76595745 & 100,0542619 & 53,84615385 & 2,379707896 \\
\hline & & TA & 33,65811966 & 46,53038709 & 92,70386266 & 1,005798504 \\
\hline & \multirow[t]{2}{*}{ Staked } & Chartist & 79,54468085 & 99,3062103 & 55,12820513 & 2,373679919 \\
\hline & & TA & 29,63675214 & 41,81833933 & 93,56223176 & 0,890396625 \\
\hline \multirow{4}{*}{$\begin{array}{l}\text { PT. A } \\
\text { International } \\
\text { Tbk (ASII) }\end{array}$} & \multirow[t]{2}{*}{ Shallow } & Chartist & 106,5276596 & 137,6830773 & 50,85470085 & 1,493366786 \\
\hline & & TA & 56,33760684 & 67,50508053 & 96,99570815 & 0,809927247 \\
\hline & \multirow[t]{2}{*}{ Staked } & Chartist & 103,8212766 & 136,1219103 & 51,70940171 & 1,45395854 \\
\hline & & TA & 47,37179487 & 60,50482074 & 97,85407725 & 0,677825422 \\
\hline \multirow{4}{*}{$\begin{array}{l}\text { PT. Indomobil } \\
\text { Sukses } \\
\text { Internasional } \\
\text { Tbk (IMAS) }\end{array}$} & \multirow[t]{2}{*}{ Shallow } & Chartist & 62,05957447 & 85,332541 & 55,98290598 & 3,28997247 \\
\hline & & TA & 82,72649573 & 109,2502812 & 93,13304721 & 4,1608269 \\
\hline & \multirow[t]{2}{*}{ Staked } & Chartist & 58,78297872 & 79,42307934 & 55,55555556 & 3,276845625 \\
\hline & & TA & 61,71794872 & 98,23902475 & 92,27467811 & 2,967832934 \\
\hline \multirow{2}{*}{$\begin{array}{l}\text { PT.Telekomuni } \\
\text { kasi Indonesia }\end{array}$} & \multirow[t]{2}{*}{ Shallow } & Chartist & 48,9234043 & 63,6199821 & 50,0000000 & 1,2229222 \\
\hline & & TA & 20,1068376 & 28,1459110 & 97,8540773 & 0,5114257 \\
\hline \multirow{2}{*}{$\begin{array}{l}\text { (Persero) } \\
\text { (TLKM }\end{array}$} & \multirow[t]{2}{*}{ Staked } & Chartist & 48,0382979 & 61,9451714 & 50,4273504 & 1,1971767 \\
\hline & & TA & 14,6880342 & 19,1852196 & 98,2832618 & 0,3681199 \\
\hline \multirow{4}{*}{$\begin{array}{l}\text { PT. G } \\
\text { Indonesia } \\
\text { (Persero) } \\
\text { (GIAA) }\end{array}$} & \multirow[t]{2}{*}{ Shallow } & Chartist & 16,65106383 & 23,25611336 & 55,12820513 & 3,437270465 \\
\hline & & TA & 10,84615385 & 14,27208141 & 90,55793991 & 2,20413261 \\
\hline & Staked & Chartist & 15,74893617 & 22,21471623 & 57,69230769 & 3,28413903 \\
\hline & & TA & 10,54273504 & 13,57111689 & 90,55793991 & 2,161819392 \\
\hline
\end{tabular}

Pada Tabel 4 dapat diamati nilai error (MAE, RMSE, MAPE) memiliki nilai terendah pada model arsitektur Stacked dengan data input TA. Nilai DA tertinggi terdapat pada arsitektur Stacked dengan data input TA. Namun pada satu kasus pada perusahaan IMAS nilai error terbaik terdapat model dengan Staked dengan data input chartist.

\subsection{Label 3 Hari}

Berikut adalah daftar model dengan nilai pengujian terbaik pada jumlah unit setiap perusahaan, arsitektur, dan data input dengan label 3 hari.

Tabel 5. Nilai metode pengujian jumlah unit GRU terbaik

\begin{tabular}{|c|c|c|c|c|c|c|c|}
\hline \multicolumn{2}{|c|}{ Perusahaan } & Arsitektur & $\begin{array}{l}\text { Input } \\
\text { Data }\end{array}$ & MAE & RMSE & $\mathrm{DA}$ & MAPE \\
\hline \multirow{4}{*}{$\begin{array}{l}\text { PT. } \\
\text { Energy } \\
\text { (ADRO) }\end{array}$} & \multirow{4}{*}{$\begin{array}{r}\text { Adaro } \\
\text { Tbk }\end{array}$} & \multirow[t]{2}{*}{ Shallow } & Chartist & 52,02978723 & 67,30163919 & 55,98290598 & 3,922477447 \\
\hline & & & TA & 49,61802575 & 63,31042805 & 50 & 3,778974184 \\
\hline & & \multirow[t]{2}{*}{ Staked } & Chartist & 51,47234043 & 66,0863394 & 58,11965812 & 3,917572553 \\
\hline & & & TA & 41,39484979 & 52,28795313 & 50,86206897 & 3,153169922 \\
\hline \multirow{4}{*}{$\begin{array}{l}\text { PT. } \\
\text { Indonesia } \\
\text { (INCO) }\end{array}$} & \multirow{4}{*}{$\begin{array}{l}\text { Vale } \\
\text { Tbk }\end{array}$} & \multirow[t]{2}{*}{ Shallow } & Chartist & 134,3744681 & 167,3780534 & 54,27350427 & 4,023522226 \\
\hline & & & TA & 110,4206009 & 133,6914005 & 46,55172414 & 3,328201546 \\
\hline & & \multirow[t]{2}{*}{ Staked } & Chartist & 130,2723404 & 162,3774431 & 53,84615385 & 3,897615474 \\
\hline & & & TA & 110,7896996 & 134,2477691 & 48,70689655 & 3,328168893 \\
\hline
\end{tabular}


Tabel 5. Nilai metode pengujian jumlah unit GRU terbaik

\begin{tabular}{|c|c|c|c|c|c|c|}
\hline Perusahaan & Arsitektur & $\begin{array}{l}\text { Input } \\
\text { Data }\end{array}$ & MAE & RMSE & DA & MAPE \\
\hline \multirow{4}{*}{$\begin{array}{l}\text { PT. Astra } \\
\text { International } \\
\text { Tbk (ASII) }\end{array}$} & \multirow[t]{2}{*}{ Shallow } & Chartist & 170, & 213,4 & 57,264 & 2,39184272 \\
\hline & & TA & 143,5 & 185,8539161 & 53,017 & 2,01624146 \\
\hline & \multirow[t]{2}{*}{ Staked } & & 161, & 200,3 & 56,4 & 76827 \\
\hline & & TA & 144 & 187 & & \\
\hline \multirow{4}{*}{$\begin{array}{l}\text { PT. Indomobil } \\
\text { Sukses } \\
\text { Internasional } \\
\text { Tbk (IMAS) }\end{array}$} & \multirow[t]{2}{*}{ Shallow } & & 946 & & & 4,7 \\
\hline & & TA & 124 & & & 128 \\
\hline & \multirow[t]{2}{*}{ Staked } & $\mathrm{Ch}$ & 96 & & & 378 \\
\hline & & TA & 8 & & & 4,1 \\
\hline \multirow{2}{*}{$\begin{array}{l}\text { PT.Telekomuni } \\
\text { kasi Indonesia }\end{array}$} & \multirow[t]{2}{*}{ Shallow } & & 74,8 & & & 1,8 \\
\hline & & TA & 65,1 & 85,218 & 47,8 & 1,621279977 \\
\hline \multirow{2}{*}{$\begin{array}{l}\text { (Persero) } \\
\text { (TLKM }\end{array}$} & \multirow[t]{2}{*}{ Staked } & Chartist & 74 & 91,88 & 53,8 & 1,844086939 \\
\hline & & TA & 62,7 & 81, & 49 & 438868 \\
\hline \multirow{4}{*}{$\begin{array}{l}\text { PT. G } \\
\text { Indonesia } \\
\text { (Persero) } \\
\text { (GIAA) }\end{array}$} & \multirow[t]{2}{*}{ Shallow } & Chartist & 24,83 & 33,13582621 & 55,98290598 & 5,199395772 \\
\hline & & TA & 22,02575107 & 28,79154025 & 55,17241379 & 4,61629905 \\
\hline & Staked & Chat & 24,43829787 & 33,0101854 & 56,41025641 & 5,120791546 \\
\hline & & TA & 21,89699571 & 28,35686139 & 56,46551724 & 4,618997971 \\
\hline
\end{tabular}

Pada Tabel 5 dapat diamati nilai error (MAE, RMSE, MAPE) memiliki nilai terendah pada model arsitektur Stacked dengan data input TA. Namun pada perusahaan INCO dan ASII perbedaan arsitektur tidak berpengaruh. Nilai DA tertinggi tidak memiliki arsitektur spesifik maupun data input spesifik yang mempengaruhinya.

\subsection{Label 1 Minggu}

Berikut adalah daftar model dengan nilai pengujian terbaik pada jumlah unit setiap perusahaan, arsitektur, dan data input dengan label 1 minggu.

Tabel 6. Nilai metode pengujian jumlah unit GRU terbaik

\begin{tabular}{|c|c|c|c|c|c|c|}
\hline Perusahaan & Arsitektur & $\begin{array}{l}\text { Input } \\
\text { Data }\end{array}$ & MAE & RMSE & DA & MAPE \\
\hline \multirow{4}{*}{$\begin{array}{l}\text { PT. } \\
\text { Energy } \\
(\text { ADRO) }\end{array}$} & \multirow[t]{2}{*}{ Shallow } & Chartist & 89,63247863 & 110,7637819 & 52,78969957 & 6,879468495 \\
\hline & & TA & 79,83261803 & 102,7559925 & 53,87931034 & 6,028573436 \\
\hline & \multirow[t]{2}{*}{ Staked } & Chartist & 84,1025641 & 106,958495 & 52,78969957 & 6,392296868 \\
\hline & & TA & 75,59656652 & 96,73054473 & 51,72413793 & 5,742310919 \\
\hline \multirow{4}{*}{$\begin{array}{l}\text { PT. } \\
\text { Indonesia } \\
\text { (INCO) }\end{array}$} & \multirow[t]{2}{*}{ Shallow } & Chartist & 183,7863248 & 227,3926158 & 49,35622318 & 5,574260114 \\
\hline & & TA & 178,9484979 & 220,4957641 & 51,29310345 & 5,401855334 \\
\hline & \multirow[t]{2}{*}{ Staked } & Chartist & 179,6282051 & 225,2256134 & 52,36051502 & 5,151144294 \\
\hline & & TA & 181,1416309 & 220,8217 & 53,87931034 & 5,468198351 \\
\hline \multirow{4}{*}{$\begin{array}{l}\text { PT. As } \\
\text { International } \\
\text { Tbk (ASII) }\end{array}$} & \multirow[t]{2}{*}{ Shallow } & Chartist & 248,034188 & 309,7636954 & 57,08154506 & 3,494792462 \\
\hline & & TA & 231,3218884 & 287,984844 & 52,15517241 & 3,256202421 \\
\hline & \multirow[t]{2}{*}{ Staked } & Chartist & 243,9273504 & 302,9480577 & 57,51072961 & 3,444700366 \\
\hline & & TA & 231,695279 & 292,5371258 & 51,29310345 & 3,260423553 \\
\hline \multirow{4}{*}{$\begin{array}{l}\text { PT. Indomobil } \\
\text { Sukses } \\
\text { Internasional } \\
\text { Tbk (IMAS) }\end{array}$} & \multirow[t]{2}{*}{ Shallow } & Chartist & 160,1495726 & 204,1555779 & 58,79828326 & 7,963986993 \\
\hline & & TA & 152,3562232 & 186,7822284 & 56,46551724 & 7,201708974 \\
\hline & \multirow[t]{2}{*}{ Staked } & Chartist & 150,440 & 202,6 & 58,36 & 7,749394369 \\
\hline & & TA & 141,9399142 & 172,6151789 & 56,46551724 & 6,83669892 \\
\hline PT.Telekomuni & Shallow & Chartist & 100,6196581 & 127,4812036 & 54,93562232 & 2,512731174 \\
\hline
\end{tabular}


Tabel 6. Nilai metode pengujian jumlah unit GRU terbaik

\begin{tabular}{ccccccc}
\hline Perusahaan & Arsitektur & $\begin{array}{l}\text { Input } \\
\text { Data }\end{array}$ & MAE & RMSE & DA & MAPE \\
\hline $\begin{array}{c}\text { kasi Indonesia } \\
\text { (Persero) Tbk } \\
\text { (TLKM }\end{array}$ & Staked & TA & 93,45922747 & 121,8278177 & 53,44827586 & 2,326569391 \\
\cline { 2 - 6 } & Chartist & 97,78205128 & 122,6954572 & 55,36480687 & 2,435960731 \\
\cline { 2 - 7 } & TA & $\mathbf{8 9 , 8 7 1 2 4 4 6 4}$ & $\mathbf{1 1 7 , 0 1 5 8 2 7 4}$ & 52,15517241 & $\mathbf{2 , 2 4 2 3 0 5 8 9 3}$ \\
\hline $\begin{array}{c}\text { PT. Garuda } \\
\text { Indonesia } \\
\text { (Persero) Tbk } \\
\text { (GIAA) }\end{array}$ & Shallow & Chartist & 35,41452991 & 48,60537939 & 57,51072961 & 7,381074637 \\
\cline { 2 - 7 } & Staked & Chartist & 35,79487179 & 48,70002369 & $\mathbf{6 2 , 2 3 1 7 5 9 6 6}$ & 7,498768507 \\
\cline { 2 - 7 } & & TA & $\mathbf{3 4 , 7 4 6 7 8 1 1 2}$ & $\mathbf{4 6 , 0 3 1 9 9 1 1 1}$ & 59,05172414 & 7,34561767
\end{tabular}

Pada Tabel 6 dapat diamati nilai error (MAE, RMSE, MAPE) memiliki nilai terendah pada model arsitektur Stacked dengan data input TA pada empat perusahaan yaitu ADRO, IMAS, ,TLKM, dan GIAA. Nilai DA tertinggi pada empat perusahaan yaitu INCO, ASII, TLKM, dan GIAA dengan arsitektur Stacked. DA tertinggi pada empat perusahaan yaitu ASII, IMAS, TLKM, dan GIAA dengan data input.

\subsection{Label 2 Minggu}

Berikut adalah daftar model dengan nilai pengujian terbaik pada jumlah unit setiap perusahaan, arsitektur, dan data input dengan label 2 minggu.

Tabel 7. Nilai metode pengujian jumlah unit GRU terbaik

\begin{tabular}{|c|c|c|c|c|c|c|}
\hline Perusahaan & Arsitektur & $\begin{array}{l}\text { Input } \\
\text { Data }\end{array}$ & MAE & RMSE & DA & MAPE \\
\hline \multirow{4}{*}{$\begin{array}{l}\text { PT. } \\
\text { Energy } \\
(\text { ADRO) }\end{array}$} & \multirow[t]{2}{*}{ Shallow } & Chartist & 129,167382 & 164,0141049 & 52,5862069 & 9,963823336 \\
\hline & & TA & 112,4112554 & 145,7687637 & 54,7826087 & 8,505994893 \\
\hline & \multirow[t]{2}{*}{ Staked } & Chartist & 129,6266094 & 163,4686908 & 55,60344828 & 10,0181909 \\
\hline & & TA & 120,6103896 & 152,8833554 & 52,17391304 & 9,322231685 \\
\hline \multirow{4}{*}{$\begin{array}{l}\text { PT. } \\
\text { Indonesia } \\
\text { (INCO) }\end{array}$} & \multirow[t]{2}{*}{ Shallow } & Chartist & 222,27897 & 269,4529269 & 59,05172414 & 6,799423238 \\
\hline & & TA & 219,1774892 & 279,9283458 & 52,60869565 & 6,65135616 \\
\hline & \multirow[t]{2}{*}{ Staked } & Chartist & 221,3690987 & 265,7657412 & 60,34482759 & 6,782144935 \\
\hline & & TA & 210,991342 & 266,4264963 & 53,04347826 & 6,423489069 \\
\hline \multirow{4}{*}{$\begin{array}{l}\text { PT. A } \\
\text { International } \\
\text { Tbk (ASII) }\end{array}$} & \multirow[t]{2}{*}{ Shallow } & Chartist & 368,0901288 & 435,7749202 & 52,15517241 & 5,209412404 \\
\hline & & TA & 361,5367965 & 424,5990061 & 56,0869565 & 5,0999653 \\
\hline & \multirow[t]{2}{*}{ Staked } & Chartist & 356,6266094 & 421,6966243 & 55,60344828 & 5,032086462 \\
\hline & & TA & 347,5064935 & 411,9063799 & 54,7826087 & 4,888168101 \\
\hline \multirow{4}{*}{$\begin{array}{l}\text { PT. Indomobil } \\
\text { Sukses } \\
\text { Internasional } \\
\text { Tbk (IMAS) }\end{array}$} & \multirow[t]{2}{*}{ Shallow } & Chartist & 232,0772532 & 320,9667933 & 51,72413793 & 11,69849203 \\
\hline & & TA & 222,8571429 & 298,99077 & 56,52173913 & 10,61832479 \\
\hline & \multirow[t]{2}{*}{ Staked } & Chartist & 220,7467811 & 311,6628805 & 56,03448276 & 11,09777692 \\
\hline & & TA & 180,8398268 & 249,2418982 & 55,2173913 & 8,695445068 \\
\hline \multirow{2}{*}{$\begin{array}{l}\text { PT.Telekomuni } \\
\text { kasi Indonesia }\end{array}$} & \multirow[t]{2}{*}{ Shallow } & Chartist & 119,9227468 & 150,5643461 & 51,72413793 & 2,989828725 \\
\hline & & TA & 131,7012987 & 162,8417685 & 51,30434783 & 3,2776882 \\
\hline \multirow{2}{*}{$\begin{array}{l}\text { (Persero) Tbk } \\
\text { (TLKM }\end{array}$} & \multirow[t]{2}{*}{ Staked } & Chartist & 118,5150215 & 144,4207313 & 53,01724138 & 2,938488751 \\
\hline & & TA & 125,1038961 & 156,8034726 & 52,60869565 & 3,106360907 \\
\hline \multirow{4}{*}{$\begin{array}{l}\text { PT. G } \\
\text { Indonesia } \\
\text { (Persero) } \\
\text { (GIAA) }\end{array}$} & \multirow[t]{2}{*}{ Shallow } & Chartist & 49,93133047 & 66,86839294 & 56,89655172 & 10,12939291 \\
\hline & & TA & 49,36363636 & 65,67442326 & 57,39130435 & 10,07470806 \\
\hline & Staked & Chartist & 50,78540773 & 67,9954871 & 58,62068966 & 10,45801536 \\
\hline & & TA & 50,58008658 & 66,26236714 & 58,26086957 & 10,31055246 \\
\hline
\end{tabular}


Pada Tabel 7 dapat diamati nilai error (MAE, RMSE, MAPE) memiliki nilai terendah pada model arsitektur Stacked dengan data input TA kecuali pada dua perusahaan yaitu ADRO dan GIAA yang nilai errornya terendah jatuh pada arsitektur shallow. Nilai DA tertinggi ada pada arsitektur Stacked kecuali pada perusahaan ADRO.

\subsection{Label 1 Bulan}

Berikut adalah daftar model dengan nilai pengujian terbaik pada jumlah unit setiap perusahaan, arsitektur, dan data input dengan label 1 bulan.

Tabel 8. Nilai metode pengujian jumlah unit GRU terbaik

\begin{tabular}{|c|c|c|c|c|c|c|}
\hline Perusahaan & Arsitektur & $\begin{array}{l}\text { Input } \\
\text { Data }\end{array}$ & MAE & RMSE & DA & MAPE \\
\hline \multirow{4}{*}{$\begin{array}{lr}\text { PT. } & \text { Adaro } \\
\text { Energy } & \text { Tbk } \\
\text { (ADRO) } & \end{array}$} & \multirow[t]{2}{*}{ Shallow } & Chartist & 162,426087 & 200,7759296 & 53,71179039 & 12,97943719 \\
\hline & & TA & 143,3114035 & 181,0277555 & 58,14977974 & 11,27204926 \\
\hline & \multirow[t]{2}{*}{ Staked } & Chartist & 175,6086957 & 211,5731963 & 55,45851528 & 14,03625637 \\
\hline & & TA & 148,5964912 & 186,2940046 & 56,82819383 & 11,84032253 \\
\hline \multirow{4}{*}{$\begin{array}{ll}\text { PT. } & \text { Vale } \\
\text { Indonesia } & \text { Tbk }\end{array}$} & \multirow[t]{2}{*}{ Shallow } & Chartist & 361,1869565 & 426,5684766 & 58,95196507 & 10,69485294 \\
\hline & & TA & 368,6359649 & 454,2191825 & 49,77973568 & 10,97895215 \\
\hline & \multirow[t]{2}{*}{ Staked } & Chartist & 362,573913 & 415,1703579 & 52,83842795 & 10,892784 \\
\hline & & TA & 356,5745614 & 437,0049931 & 46,69603524 & 10,59037428 \\
\hline \multirow{4}{*}{$\begin{array}{l}\text { PT. Astra } \\
\text { International } \\
\text { Tbk (ASII) }\end{array}$} & \multirow[t]{2}{*}{ Shallow } & Chartist & 364,6565217 & 474,1031671 & 65,06550218 & 5,12832552 \\
\hline & & TA & 393,3947368 & 488,8140589 & 56,82819383 & 5,5717442 \\
\hline & \multirow[t]{2}{*}{ Staked } & Chartist & 394,7217391 & 474,2871997 & 60,69868996 & 5,548660675 \\
\hline & & TA & 337,5745614 & 447,8424937 & 54,18502203 & 4,715919276 \\
\hline \multirow{4}{*}{$\begin{array}{l}\text { PT. Indomobil } \\
\text { Sukses } \\
\text { Internasional } \\
\text { Tbk (IMAS) }\end{array}$} & \multirow[t]{2}{*}{ Shallow } & Chartist & 372,6652174 & 495,4283039 & 54,58515284 & 18,30454083 \\
\hline & & TA & 344,0438596 & 493,0455212 & 53,74449339 & 15,52341727 \\
\hline & \multirow[t]{2}{*}{ Staked } & Chartist & 341,7782609 & 496,2778543 & 53,27510917 & 15,66090983 \\
\hline & & TA & 318,9605263 & 460,7345918 & 51,10132159 & 14,61971667 \\
\hline \multirow{2}{*}{$\begin{array}{l}\text { PT.Telekomuni } \\
\text { kasi Indonesia }\end{array}$} & \multirow[t]{2}{*}{ Shallow } & Chartist & 135,9130435 & 186,903137 & 56,33187773 & 3,362249404 \\
\hline & & TA & 155,1754386 & 215,7131176 & 51,54185022 & 3,85699917 \\
\hline \multirow{2}{*}{$\begin{array}{l}\text { (Persero) } \\
\text { (TLKM }\end{array}$} & \multirow[t]{2}{*}{ Staked } & Chartist & 118,5150215 & 144,4207313 & 53,01724138 & 2,938488751 \\
\hline & & TA & 144,6403509 & 200,8643603 & 51,10132159 & 3,599550672 \\
\hline Garuda & Shallow & Chartist & 75,09130435 & 98,30562371 & 58,95196507 & 15,03716884 \\
\hline \multirow{3}{*}{$\begin{array}{l}\text { Indonesia } \\
\text { (Persero) } \\
\text { (GIAA) }\end{array}$} & & TA & 77,25 & 99,61278101 & 61,67400881 & 15,34439264 \\
\hline & \multirow[t]{2}{*}{ Staked } & Chartist & 78,13043478 & 106,2126251 & 60,26200873 & 15,7165925 \\
\hline & & TA & 75,62719298 & 99,33288443 & 62,55506608 & 15,03748716 \\
\hline
\end{tabular}

Pada Tabel 8 dapat diamati nilai error (MAE, RMSE, MAPE) memiliki nilai terendah pada model arsitektur Stacked kecuali pada dua perusahaan yaitu ADRO dan GIAA. Nilai error terendah terdapat pada data input TA kecuali pada dua perusahaan yaitu TLKM dan GIAA. Nilai DA tertinggi ada pada arsitektur Stacked dan data input chartist kecuali pada perusahaan ADRO dan GIAA.

\subsection{Perbandingan Perusahaan Berdasarkan Liquiditas}

Pada Gambar 6 dapat diamati perusahaan Liquid memiliki MAPE yang lebih rendah dari pada perusahaan non-liquid. Hanya 3 kasus dari perbandingan perusahaan liquid dan non liquid dimana perusahaan non liquid memiliki nilai MAPE yang lebih rendah dari pada perusahaan non liquid yaitu pada sektor mining pada tiga label (1 minggu, 2 minggu, 1 bulan). Perusahaan INCO (non liquid) mempunyai nilai MAPE yang lebih rendah daripada ADRO (liquid). Perbedaan nilai MAPE pada tiga kasus tersebut tidak signifikan. Gambar 6 merupakan visualisasi dari Tabel 9. 
Tabel 9. Perbandingan perusahaan label 1 hari dan 3 hari

\begin{tabular}{llllllll}
\hline Sektor & Perusahaan & MAPE & & & & \\
\cline { 3 - 7 } & & $\begin{array}{l}\text { Label } \\
1 \text { hari }\end{array}$ & $\begin{array}{l}\text { Label } \\
3 \text { hari }\end{array}$ & $\begin{array}{l}\text { Label } \\
\text { minggu }\end{array}$ & $\begin{array}{l}\text { Label } \\
\text { minggu }\end{array}$ & $\begin{array}{l}\text { Label } \\
\text { bulan }\end{array}$ \\
\hline \multirow{2}{*}{ Mining } & ADRO & 0,836405 & 3,153169922 & 5,742310919 & 9,322231685 & 11,27204926 \\
\cline { 2 - 7 } & INCO & 0,890397 & 3,328168893 & 5,151144294 & 8,505994893 & 10,59037428 \\
\hline Miscellenous & ASII & 0,677825 & 2,01624146 & 3,256202421 & 5,032086462 & 4,715919276 \\
\cline { 2 - 8 } & IMAS & 2,967833 & 4,145833272 & 6,83669892 & 8,695445068 & 14,61971667 \\
\hline \multirow{2}{*}{ Infrastructure } & TLKM & 0,36812 & 1,565438868 & 2,242305893 & 2,938488751 & 2,938488751 \\
\cline { 2 - 8 } & GIAA & 2,161819 & 4,61629905 & 7,233046732 & 10,07470806 & 15,03716884 \\
\hline
\end{tabular}

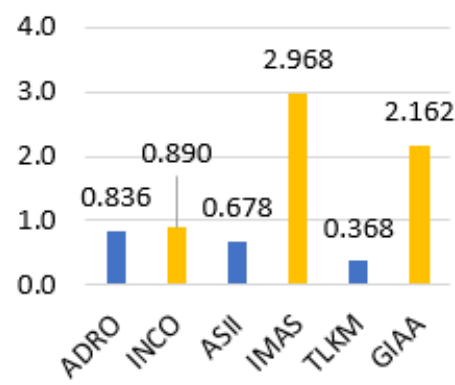

Label 1 hari

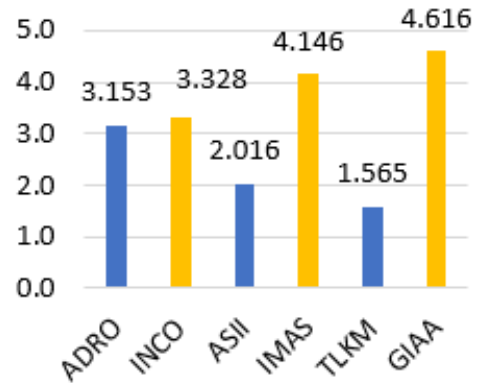

Label 3 hari

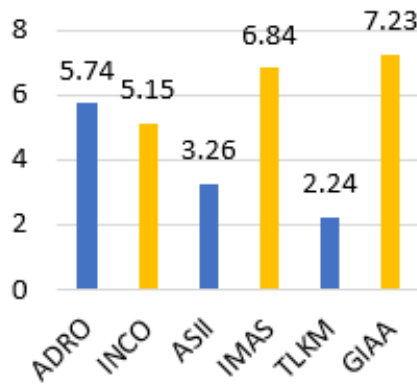

Label 1 minggu

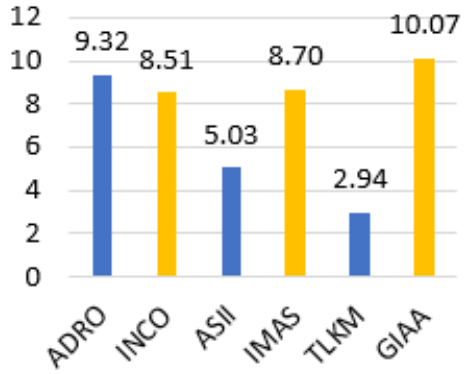

Label 2 minggu

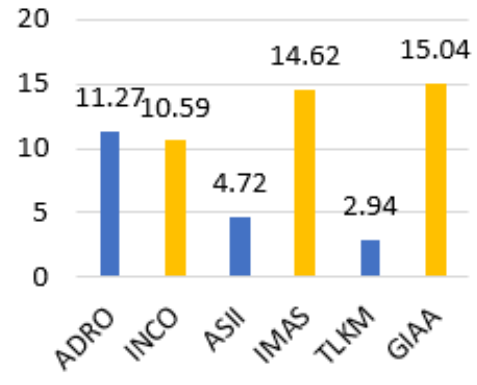

Label 1 bulan

Gambar 6. Perbandingan Perusahaan

\subsection{Model dengan Implementasi Regulasi Dropout}

Sebagian besar model dengan regulasi Dropout tidak dapat menurun kan nilai error (MAE, RMSE, MAPE) dan meningkatkan nilai DA. Dari 120 model (5 label x 6 perusahaan x 4 model terbaik setiap perusahaan) yang diterapkan regulasi Dropout hanya 43 model yang nilai errornya turun. Dari 43 model yang nilai error turun dan DA naik 6 model terdapat pada label 1 hari, 7 model terdapat pada model label 3 hari, 11 model terdapat pada model label 1 minggu, 8 model terdapat pada label 2 minggu, dan 11 model terdapat pada model label 1 bulan.

\section{Kesimpulan dan Saran}

Dari penelitian yang telah dilakukan, maka diperoleh kesimpulan sebagai berikut. Jumlah unit/neuron yang diujikan pada model metode RNN-GRU tidak memiliki jumlah unit/neuron 
yang sama pada semua kasus prediksi pada penelitian ini. Setiap perusahaan, arsitektur model dan data input memiliki banyak unit/neuron terbaik yang berbeda-beda. Metode pengujian (MAE, RMSE, DA, dan MAPE) pada beberapa kasus pengujian memiliki jumlah unit terbaik pada model yang berbeda-beda. Semakin jauh model RNN-GRU memprediksi nilai saham maka nilai error (MAE, RMSE, MAPE) akan semakin besar. Pada penelitian ini yang menggunakan lima label (1 hari, 3 hari, 1 minggu, 2 minggu, 1 bulan), nilai error dari label 1 hari menuju 1 bulan memiliki kenaikan secara konstan. Hal ini terjadi pada setiap pengujian Perusahaan, arsitektur, dan data input.

Arsitektur Stacked merupakan arsitektur yang lebih stabil daripada Shallow dalam menghasilkan nilai error yang rendah (MAE, RMSE, MAPE) dan menghasilkan nilai DA yang tinggi. Walaupun dalam beberapa kasus pada penelitian ini arsitektur Shallow dapat menghasilkan nilai error yang rendah dan DA yang tinggi dibandingkan Stacked tetapi pada 30 kali perbandingan arsitektur (5 label x 6 perusahaan) arsitektur Stacked dapat mengungguli Shallow sebanyak 21 kali dalam rendahnya nilai error dan 19 kali dalam tingginya nilai DA. Data input TA merupakan data input yang mampu menghasilkan nilai error (MAE, RMSE, MAPE) yang rendah daripada data input chartist. Walaupun dalam beberapa kasus pada penelitian ini data input Chartist dapat unggul dalam rendahnya nilai error namun pada 30 kali perbandingan data input (5 label x 6 perusahaan) data input TA dapat mengungguli chartist sebanyak 25 kali dalam rendahnya nilai error. Tetapi pada penelitian ini data input chartist mengungguli data input TA dalam tingginya nilai DA sebanyak 15 kali dari 30 kali perbandingan. Perusahaan Liquid lebih mudah diprediksi oleh model RNN-GRU dari pada non liquid. Nilai MAPE pada perusahaan Liquid lebih rendah daripada perusahaan non liquid. Dropout tidak berpengaruh terhadap turunnya nilai error pada model RNN-GRU.

Penelitian ini masih terdapat kekurangan dan keterbatasan. Kekurangan dan keterbatas ini diharapkan menjadi pertimbangan dan acuan pada penelitian selanjutnya. Penelitian ini belum dapat menyelesaikan masalah tingginya nilai error pada model yang melakukan prediksi lebih dari tiga hari kedepan. Model yang melakukan prediksi lebih dari tiga hari kedepan membutuhkan perlakuan data dan analisis pembangunan model yang lebih dalam.

\section{Daftar Pustaka}

[1] Althelaya, K.A., El-Alfy, E.S.M. and Mohammed, S., 2018. Stock Market Forecast Using Multivariate Analysis with Bidirectional and Stacked (LSTM, GRU). 21st Saudi Computer Society National Computer Conference, NCC 2018, pp.1-7.

[2] Chen, J.X., Jiang, D.M. and Zhang, Y.N., 2019. A Hierarchical Bidirectional GRU Model With Attention for EEG-Based Emotion Classification. IEEE Access, 7, pp.118530-118540.

[3] Chung, J., Gulcehre, C., Cho, K. and Bengio, Y., 2014. Empirical Evaluation of Gated Recurrent Neural Networks on Sequence Modeling. [online] pp.1-9. Available at: <http://arxiv.org/abs/1412.3555>.

[4] Faurina, R., 2019. Klasifikasi Pergerakan Harga Saham Jangka Pendek Menggunakan Principal Component Analysis dan Jaringan Long Short Term Memory : Studi Kasus Pada Saham Bursa Efek Indonesia. S2. Universitas Gajah Mada 
[5] Fu, R., Zhang, Z. and Li, L., 2016. Using LSTM and GRU Neural Network Methods for Traffic Flow Prediction. 31st Youth Academic Annual Conference of Chinese Association of Automation Wuhan, pp.324-328.

[6] Guresen, E., Kayakutlu, G. and Daim, T.U., 2011. Using artificial neural network models in stock market index prediction. Expert Systems with Applications, [online] 38(8), pp.10389-10397. Available at: <http://dx.doi.org/10.1016/j.eswa.2011.02.068>.

[7] Id, T.A.R., Abbas, D.K. and Turel, Y.K., 2019. A multi hidden recurrent neural network with a modified grey wolf optimizer. PLOS ONE, [online] pp.1-23. Available at: 〈https://doi.org/10.1371/journal.pone.0213237>.

[8] Imandoust, S.B. and Bolandraftar, M., 2014. Forecasting the direction of stock market index movement using three data mining techniques: the case of Tehran Stock Exchange. Journal of Engineering Research and Applications www.ijera.com, [online] 4(6), pp.106-117. Available at: 〈www.ijera.com>.

[9] Kara, Y., Acar Boyacioglu, M. and Baykan, Ö.K., 2011. Predicting direction of stock price index movement using artificial neural networks and support vector machines: The sample of the Istanbul Stock Exchange. Expert Systems with Applications, [online] 38(5), pp.5311-5319. Available at: <http://dx.doi.org/10.1016/j.eswa.2010.10.027>.

[10] Khoolish, N, T.(2019). Gated Recurrent Unit - Recurrent Neural Network Untuk Peramalan Nilai Tukar Mata Uang Rupiah Terhadap Dolar Amerika. S1. Universitas Gajah Mada

[11] Kui, lin L., Chun, jiw Z. and Jian, min X., 2017. Short term traffic flow prediction Using methodology based on arima and RBF-ANN. IEEE, p.634.

[12] Kumar, S., Hussain, L., Banarjee, S. and Reza, M., 2018. Energy Load Forecasting using Deep Learning Approach-LSTM and GRU in Spark Cluster. Proceedings of 5th International Conference on Emerging Applications of Information Technology, EAIT 2018, pp.1-4.

[13] Ma, T., Antoniou, C. and Toledo, T., 2020. Hybrid machine learning algorithm and statistical time series model for network-wide traffic forecast. Transportation Research Part C: Emerging Technologies, [online] 111(December 2019), pp.352372. Available at: <https://doi.org/10.1016/j.trc.2019.12.022>.

[14] Ratnayaka, R.M.K.T., Seneviratne, D.M.K.N., Jianguo, W. and Arumawadu, H.I., 2015. A hybrid statistical approach for stock market forecasting based on Artificial Neural Network and ARIMA time series models. 2015 International Conference on Behavioral, Economic and Socio-Cultural Computing, BESC 2015, (Besc), pp.54-60.

[15] Sugiartawan, P., Pulungan, R. and Sari, A.K., 2017. Prediction by a Hybrid of Wavelet Transform and Long-Short-Term-Memory Neural Network. International Journal of Advanced Computer Science and Applications, Vol. 8, No.2 (June), pp.326-332.

[16] Struye, J. and Latré, S., 2020. Hierarchical temporal memory and recurrent neural networks for time series prediction: An empirical validation and reduction to 
multilayer perceptrons. Neurocomputing, [online] 396(xxxx), pp.291-301. Available at: 〈https://doi.org/10.1016/j.neucom.2018.09.098>.

[17] Tambunan, A. P., 2007. Menilai Harga Wajar Saham. Jakarta: Penerbit PT Elek Media Komputindo

[18] Wang, J., Yan, J., Li, C., Gao, R.X. and Zhao, R., 2019. Deep heterogeneous GRU model for predictive analytics in smart manufacturing: Application to tool wear prediction. Computers in Industry, [online] 111, pp.1-14. Available at: <https://doi.org/10.1016/j.compind.2019.06.001>.

[19] Wira, D., 2014. Analisis Fundamenal Saham Edisi Kedua. Jakarta: Penerbit Exceed Books

[20] Zhang, D. and Kabuka, M.R., 2018. Combining weather condition data to predict traffic flow: A GRU-based deep learning approach. IET Intelligent Transport Systems, 12(7), pp.578-585. 